\title{
A CASE OF PARATYPHOID B. INFECTION WITH PURPURA AND SPECIFIC BRONCHO-PNEUMONIA.
}

\author{
BY
}

\author{
H. P. JAMESON, M.B., B.Sc., \\ and
}

A. SIGNY, L.R.C.P., M.R.C.S.

(From the Hospital for Sick Children, Great Ormond Street).

The recent epidemic of paratyphoid fever in London has sent several children suffering from the disease to this hospital. One case was so remarkable, and so rapidly fatal after admission, that it deserves record, especially since the bacteriology of the various lesions was clearly established.

A good history from the parents, dctails from the family doctor, with charts from the local hospital, made a full account of the early stages possible and reasonably accurate.

Frances P., aged 8 years, kecame ill on July 15th, 1928, complaincd of headache, and vomited once or twice. Until that day she had been quite well, and had been helping with the hay harvest. Next day her kowcls were opened several times; loose motions were passed, but no blood. On July 17 th her doctor was called, who found a high temperature, but no other physical signs.

A week later two or thrce red spots were noticed on the abdomen, and the temperature fell, to rise again the same day. The patient's condition was much improved and on the 25th and 26 th she was dressed and brought downstairs, but not allowed to walk alcout.

On the strength of a Widal reaction positive to B. paratyphosus B. on July 28 th, the child was taken to a local hospital. The sarac evening her temperature rose to $104^{\circ}$, remained there for eight hours, and was reduced by sponging. The pulse rate at this time was only 104 per min. After falling to normal, the temperature became remittent at about $100^{\circ}$, and rose slowly during the next six days to $101 \cdot 5^{\circ}$. On July 36 th small purpuric patches were noticed on the lips and neck ; then an echymosis into one conjunctiva, and a day or two later patches of purpura apreared on the trunk. Hæmaturia followed closely on the appearance of skin hæmorrhages, and on Aug. 4th and 5th the patiert vomited blood. The pulse rate which was 70 to 84 per min. until the evening of Aug. 1st, began to rise and was soon varying between 100 and 120 per min.

Aug. 5th. Patient was admitted to the Hospital for Sick Children, Great Ormond Street. She was blanched, and so ill that no detailed examination was made. Purpuric patches and petechiæ were scattered irregularly on the face, neck, and chest ; a clot disfigured the left conjunctiva, and a bruise showed faintly over the left ankle.

An hour after admission $250 \mathrm{c.cm}$. of whole blood, from the father, were given into the left median basilic vein, and later Hæmoplastin was injected intramuscularly.

The pulse rate rose after this operation, but its volume was increased, and the colour of the patient's lips and cheeks improved.

Aug. 6th. Pyrexia and vomiting continued. In the evening the patient cricd out as if in abdominal pain, became very restless and vomited an ounce and a half of thick tarry fluid on the edge of which was a little bright red blood. Morphia was given. The pulse rate rose during the day to 152 per min. and the respiratory rate was steady at 28 per min. 
Aug. 7th and 8th. During the next two days the patient seemed to hold her own. She vomited twice only, and the pulse though rapid was of fair volume. During this time the respiratory rate rose from 28 to 44 per min., and the patient was only semi-conscious. A blood culture and Widal test were made and the blood cells and platelets counted.

Aug. 9th. During the 9th extreme restlessness and noisy delirium exhausted the child, but at 10.30 p.m. she had a fair pulse, at 160 per min. Her temperature was $101^{\circ}$. An hour later she was seen in a state of acute heart failure. She was comatose, the radial pulse had vanished, and there was increasing pulmonary œdema : in an hour she was dead.

\section{Laboratory Examinations.}

Five cubic centimetres of blood were taken on Aug. 7th when the patient's temperature was $103^{\circ}$. Cultures of this in broth, and enriched broth media remained sterile after four days' inoculation at $37^{\circ} \mathrm{C}$. A Widal test on the same day showed agglutinations of B. paratyphosus B. up to a dilution of $1: 50,000$. At the same time the blood showed a marked thrombocytopenia; the platelats numbering 20,000 per c.cm., and the red cells $3,000,000$ per c.cm.

On the following day a blood count showed only $2,200,000$ red and 20,000 white cells Among these were $51 \%$ polymorphs, $31 \%$ lymphocytes, $5 \%$ myelocytes, and $9 \%$ transitional cells. Nucleated red cells were present to the extent of sixteen per hundrcd white cells. The child's grave condition prevented the repetition of these investigations.

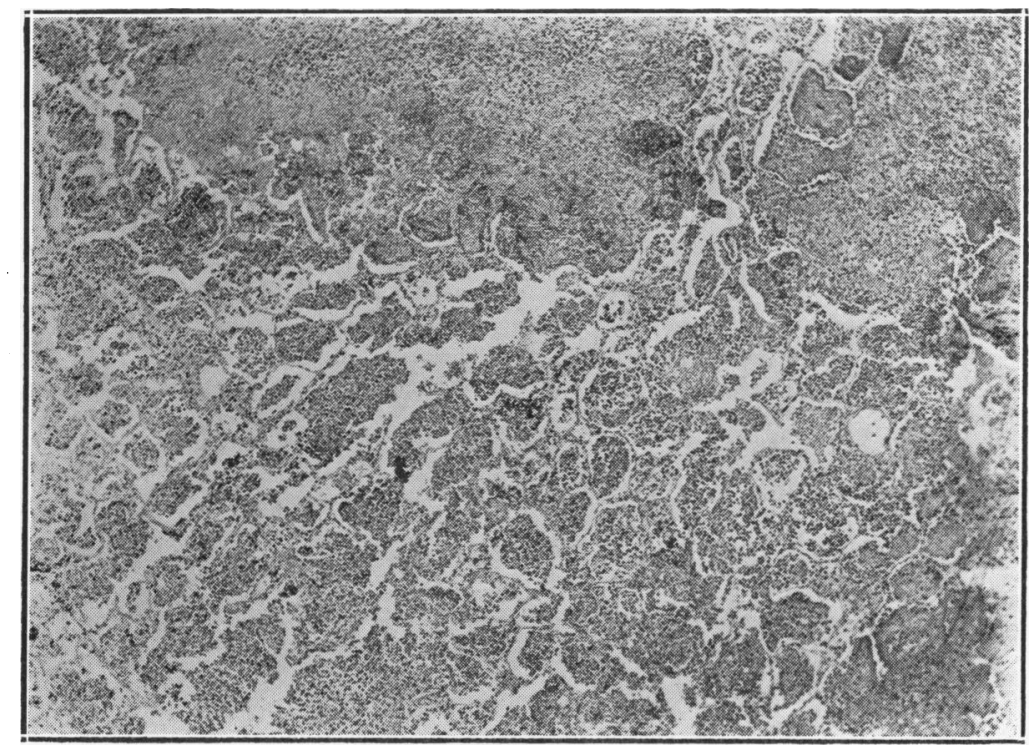

Fig. 1. Micro-section of Preumonio: Lung. ( $\frac{2}{3}$ obj. )

Post-mortem Exxinination.

A post-mortem examination was made by Dr. Moncrieff. The most striking feature was a suppurating pneumonia almost confined to one lobe. There wcre punctate hæmorrhages all over the pleuræ, and the right pleural cavity contained $1 \frac{1}{2}$ o\%. of pus. The upper lobe of the right lung was covered with purulent exudate, was solid, and showed bright orange yellow patches on section. At the apex of the left lower lobe was a similar patch with surrounding consolidation.

Microscopic sections of the lung (see Figure 1) showed exudate into the air cells with lymph atic engorgement and cellular infiltration in the interstitial tissue. Patches of necrotic lung lay next to this broncho-pneumonia, and appeared stained only by the acid dye, amorphous in structure, or containing the ghosts of alveoli, 
The mediastinal glands were slightly enlarged; there was no evidence of tuberculosis. Punctate hæmorrhages covered the pericardium and brain and were scattered over the intestines. The most extensive sub-peritoneal hæmorrhage was in the left iliac fossa which was dark with blood. The intestines showed no enlargement of Peyers patches and no ulcers in the small gut. In the large bowel several solitary follicles were enlarged, and one or two were beginning to break down. The mesenteric glands were not enlarged. The spleen weighed $50 \mathrm{grm}$., and was soft : the liver weighed 700 grm., and showed extensive fatty degeneration.

\section{Bacteriology.}

When discovered, the empyema pus was contaminated, but swabs were taken from the broncho-pneumonic lung, and from a large mediastinal gland. From each B. coli and nonlactose-fermenting organisms were grown. The latter when isolated, gave sugar reactions typical of B. paratyphosus B. Milk was turned slightly acid, but did not later become alkaline. These organisms were agglutinated strongly by the standard agglutinins sera for paratyphoid B. of the Medical Research Council. This was taken as evidence that the pneumonia was specific and due to $B$. paratyphosus $B$.

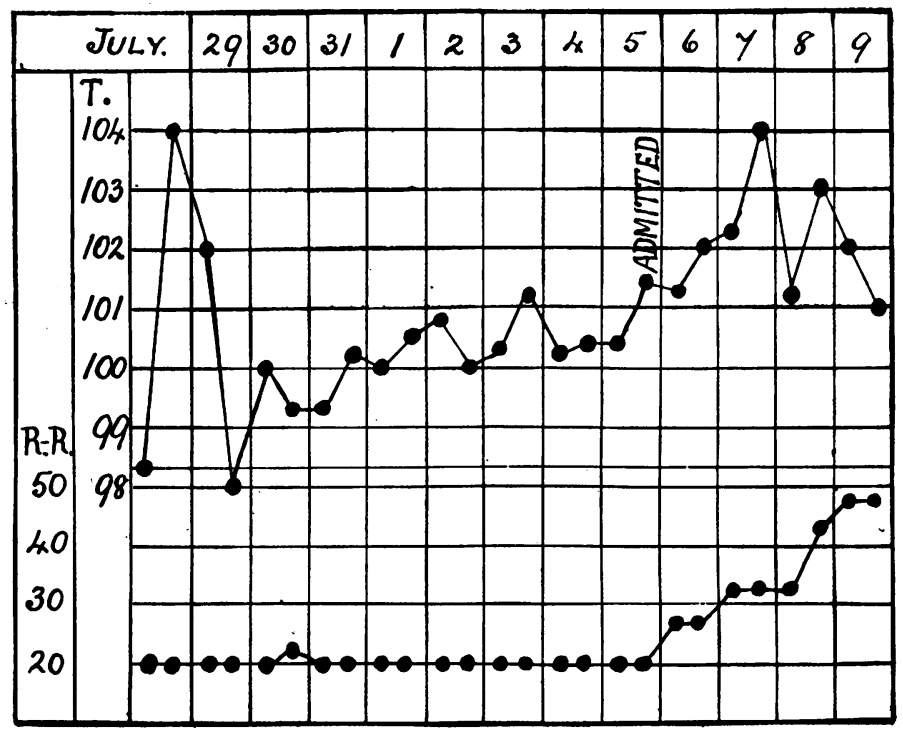

Fig. 2. Chart showing Temperatore and Regpiration rate.

The interesting points in the laboratory and pathological findings are :-

1. The extent of suppuration in the lung lesions, and the recovery of specific organisms from the lungs and mediastinal glands.

2. The leucocytosis of 20,000 per c.cm. where a leucopenia and relative lymphocytosis were to be expected. This must have been the result of reaction to suppuration in the lung.

3. The extremely high titre of agglutination in the patient's blood in the short time (three weeks) from the commencement of the illness. This indicates a good response by the production of specific anti-bodies.

4. The almost complete absence of any intestinal lesions although this is supposed to be the portal of entry of the infection. 


\section{Discussion.}

Pneumonia is apparently a common complication of fatal cases of paratyphoid infection. In 1915 Lord Dawson ${ }^{1}$ described four instances in fifteen autopsies on adults. In one of these there was cavitation with bronchopneumonia, but this had not the bright orange appearance of the suppurating lung we found. Stolkind ${ }^{2}$ noted broncho-pneumonia in eight out of eleven autopsies, and the recovery of the organism from the blood in a large proportion of these cases emphasized the septicæmic nature of the disease. The occurrence of this complication was reviewed in 1921 by Pincsohn ${ }^{3}$ who quoted cases of paratyphoid A with specific pneumonia, infarcts and hæmoptysis. Pneumonia appears to be commoner in paratyphoid $A$ than in paratyphoid B. Lemière and Loeper ${ }^{5}$ in the next year each quoted a case of paratyphoid B. septicæmia with lobar pneumonia. Both cases recovered. The lung suppuration we describe may be allied to such complications as osteitis and purulent thyroiditis that have been described by various authors. It is possible that in the present case the brunt of a paratyphoid septicæmia fell upon the lungs, and that, when these broke down with formation of abscesses, the systemic circulation was further infected with a massive and fatal dose of micro-organisms.

In 1907, Keany ${ }^{6}$ shewed a case of typhoid fever complicated by purpura. Vincent and Muratet ${ }^{7}$ mention that purpura may occur during typhoid, and express the opinion that its presence always makes the prognosis grave. Roubier and Brette $^{8}$ in 1919 emphasized the rarity of this complication. They made a distinction between a 'heralding purpura' and one which occurs during defervescence or convalescence.' Of this 'purpura tardif' they recorded two cases in adults. In both purpura appeared after the temperature had fallen, was confined to the lower limbs, and in one case it was associated with hæmaturia. Both cases recovered, and the authors gave it as their opinion that this late purpura is the less dangerous, in spite of the fact that several fatal cases had at that time been recorded. In a discussion.on paratyphoid infections at the Royal Society of Medicine in $1916^{1}$ purpura was not mentioned, and in 1918 Stolkind $^{2}$ reviewed all the literature of paratyphoid in children without referring to this complication. A case was recorded by Trabaud ${ }^{\circ}$ in 1923 of an adult male with paratyphoid A. and jaundice, in whom defervescence was complicated by a purpuric and erythematous eruption all over the body, accompanied and followed by a right lower lobar pneumonia. The patient recovered, the jaundice being the last sign to disappear. Gwosz ${ }^{1 \mathrm{c}}$ in 1927 reported general purpura, with bleeding gums, epistaxis and melæna in a child of five years, on the twenty-first day of paratyphoid B. fever. The hæmorrhages increased and two days later hæmaturia appeared. Argoflavine was given intravenously; no further hæmorrhages appeared after the 25th day and the patient recovered. This case showed a progressive leucopenia to 4,900 white cells with eosinophilia on the 23 rd day of the illness. The count rose to 7,400 on the 26 th day as the hæmorrhages decreased. At the onset, of the purpura there was marked thrombocytopenia, the platelets being only 
100,000 per c.mm. They rose to 264,000 on the 34 th day of the illness. The author admits that in view of previous cases the recovery in this case was an unusual termination and attributes it to the administration of argoflavine.

Many authors stress the variability of intestinal lesions. Two of Lord Dawson's cases (1916) showed none, and in one case lesions were confined to the large bowel. In two only of Stolkind's eleven cases was there severe folli cular enteritis. Holwede ${ }^{11}$ reports one autopsy at eight months, at which a bilateral pulmonary consolidation with empyema, was found. Ulceration was almost entirely confined to the large intestine.

During the last twenty years at the Hospital for Sick Children, there have been only two autopsies on proved cases of paratyphoid $B$. and one on a case of paratyphoid C. infection.

The first (1915) in a child of 11 years, showed no enlargement of Peyers patches, but swelling of the solitary follicles was present, without enlargement of the mesenteric glands. Bronchopneumonia and empyema were present.

The second (1921) in a baby aged six months, showed catarrhal inflammation of the large bowel only. B. paratyphosus B. had been grown from the stools, and the illness had lasted six weeks.

The third (1927) in a baby aged six weeks, showed an abscess in the righthumerus from which B. paratyphosus C. was isolated. There were no intestinal lesions.

It would be of interest to discover why some of these apparently typical cases of paratyphoid infection should suddenly develop purpura. Vincent and Muratet say that the platelet count is always low in typhoid and may be only 50 per 100,000 red cells. Damage tc the cardiovascular system by toxins, and an extreme deficiency in certain components of the blood, may each occur in this disease. The relative importance of these phenomena in the causation of purpura remains uncertain. It is possible that even in association they are only predisposing causes.

In the case that we report, an early infection of the lungs may have been followed by a massive systemic infection, of which the purpura was merely a toxic manifestation. It the records of the respiratory rate (Fig. 2) are accurate; however, it seems likely that extensive lung c.amage did not occur until late in the disease.

We are indebted to Dr. H. Thursfield for the opportunity of reporting this case.

\section{REFERENCES.}

1. Dawson, B., Proc. R. Soc. Med., Lond., 1915, IX (Sect. Med.), 1. Quart. J. Med. Oxf., 1916, IX, 98.

2. Stolkind, E. \& Lerry, A., Brit. J. Child. Dis., Lond., 1918, XV, 161.

3. Pincsohn, G., Deutsches Arch. f. klin. Med., Leipzig, 1921, V, 137.

4. Lemiere, A., \& Levesque, J., Bull. et mém. Soc. méd. d. hop. de Par., Paris, 1922, XIIV, 1045.

5. Loeper, M., \& Marchal, G., Loc. cit., 1045.

6. Keany, F. J., Bost. Med. \& Surg. J., Boston, 1907, CLVI, 202.

7. Vincent, H., \& Muratet, L., Typhoid and Paratyphoid Fevers, Lond., 1917.

8. Roubier, C., \& Brette, P., Progrès méd., Paris, 1919, XXXIV, 488.

9. Trabaud, L., Bull. et mém. Soc. méd. d. hôp. de Par., Paris, 1923, XLVII. 1866.

10. Gwosz, A., Arch. f. Kinderh., Stuttgart, 1927, LXXX, 140.

11. v, Holwede, B.. .Jahrb. f. Kinderh., Berl`n, 1919, LXXXVII, 87, 351, 